Cellulolytic activity of brown-rot Antrodia sinuosa at the initial stage of cellulose degradation

\title{
Sugano, Junko
}

2019-07

Sugano , J , Linnakoski , R , Huhtinen , S , Pappinen , A, Niemela , P \& Asiegbu , F O 2019

, ' Cellulolytic activity of brown-rot Antrodia sinuosa at the initial stage of cellulose degradation ' , Holzforschung : international journal of the biology, chemistry, physics and technology of wood, vol. 73 , no. 7 , pp. 673-680 . https://doi.org/10.1515/hf-2018-0145

http://hdl.handle.net/10138/321825

https://doi.org/10.1515/hf-2018-0145

cc_by_nc_nd

publishedVersion

Downloaded from Helda, University of Helsinki institutional repository.

This is an electronic reprint of the original article.

This reprint may differ from the original in pagination and typographic detail.

Please cite the original version. 
Junko Sugano*, Riikka Linnakoski, Seppo Huhtinen, Ari Pappinen, Pekka Niemelä and Fred O. Asiegbu

\section{Cellulolytic activity of brown-rot Antrodia sinuosa at the initial stage of cellulose degradation}

https://doi.org/10.1515/hf-2018-0145

Received June 23, 2018; accepted December 19, 2018; previously published online $x x$

Abstract: The initial stage of cellulose degradation has been studied via in vitro assays of fungi isolated from rotten wood in a boreal forest. Among the 37 isolates, Antrodia sinuosa appeared to be an effective cellulose degrader and was selected for studying the initial degradation process. In the liquid cultivation with carboxymethylcellulose (CMC), the increase of the mycelial dry weight coincided with the $\mathrm{pH}$ decrease of the culture medium from $\mathrm{pH} 5.7$ to 3.9 , between the $3^{\text {rd }}$ and $6^{\text {th }}$ cultivation day. At the same time, the cellulolytic activity increased; the CMCase activity increased sharply and the reducing sugars reached their maximum concentration in the culture medium. It seems that the decreasing $\mathrm{pH}$ enables the cellulose degradation by $A$. sinuos $a$ at an early stage of the process. The results of this study may be useful for a more efficient industrial application of biomass by means of brown-rot fungi.

Keywords: Antrodia sinuosa, biomass saccharification, brown-rot, cellulose degradation, CMCase, enzymatic activity, fungal pretreatment, initial stage

\section{Introduction}

Renewable biomasses are promising alternative resources for the production of biofuels and bio-materials, such as

\footnotetext{
*Corresponding author: Junko Sugano, Department of Microbiology, University of Helsinki, P.O. Box 56, Fl-00014 Helsinki, Finland; and Department of Biology, University of Turku, FI-20014 Turku, Finland, e-mail: junko.sugano@helsinki.fi. https://orcid.org/0000-00027678-867X

Riikka Linnakoski: Natural Resources Institute Finland (Luke), Latokartanonkaari 9, Fl-00790 Helsinki, Finland; and Department of Forest Sciences, University of Helsinki, P.O. Box 27, Fl-00014 Helsinki, Finland. https://orcid.org/0000-0002-3294-8088

Seppo Huhtinen and Pekka Niemelä: Herbarium, Biodiversity Unit, University of Turku, Fl-20014 Turku, Finland

Ari Pappinen: Faculty of Science and Forestry, School of Forest Sciences, University of Eastern Finland, P.O. Box 111, Fl-80101 Joensuu, Finland Fred O. Asiegbu: Department of Forest Sciences, University of Helsinki, P.O. Box 27, Fl-00014 Helsinki, Finland
}

nanocellulose and chemical feedstocks (Deepa et al. 2015; Guerriero et al. 2016), but the related processes are not easy routines. Biomasses from forestry and agricultural residues are complex and contain an interpenetration network of polysaccharides and lignin (shortly: lignocellulosics) (Kumar et al. 2016). Cellulose with its long chains of anhydroglucose is the major component (roughly around $43 \%$ ) of plant biomass. Cellulose can be degraded into the fermentable glucose by wood-rot fungi, but the degradation is slow because of the complex structure of lignocellulosics (Himmel et al. 2007). The same is true for industrial processes via several chemical and physical pretreatment steps (Mosier et al. 2005), which are expensive and polluting (Shirkavand et al. 2016). The direct biological degradation of cellulose with living fungi is an alternative and environmentally friendly saccharification method (Wan and Li 2012; van Kuijk et al. 2015).

This topic has been frequently investigated (Mathews et al. 2016; Agematu et al. 2017) and the feasibility of a fungal pretreatment as an alternative to physical and chemical cellulose conversion has been described (Keller et al. 2003; Bak et al. 2009; Shi et al. 2009; Xu et al. 2009; Dias et al. 2010; Sindhu et al. 2016). The challenges of an industrial application are the long pretreatment time and the substantial loss of cellulose and hemicelluloses (Balan 2014), and the optimization of the cultivation conditions and sugar yields (Kumar et al. 2008; Wan and Li 2012). The process development begins by the selection of suitable fungal species followed by more detailed analyses of their enzymatic capacity. The hypothesis for the present work was that a better knowledge of the initial degradation processes of cellulose is useful for the optimization of lignocellulose pretreatment for wood saccharification, for example, in terms of cellobiose and glucose formation, which could be further utilized by yeast in ethanol fermentation. This is the reason why, in the present work, a screening experiment was performed. Among the 37 fungal strains, Antrodia sinuosa (a brown-rot fungus) was found to be the most effective cellulose degrader and thus this fungus will be analyzed with more detail. This fungus was already studied concerning its growth rate, wood decay ability and culturing parameters (Schmidt and Moreth 1996; Bigelow et al. 
1998; Matheron et al. 2006). Renvall (1995) observed the early stages of conifer trunk decay by $A$. sinuosa but its cellulose degradation performance was not yet studied. The present study will fill this gap, with carboxymethylcellulose (CMC; amorphous cellulose) and a crystalline cellulose $(\mathrm{CrC})$ as model substrates. CMC is well suited to the observation of microbial cellulose degradation, while the CMCase activity can be assayed by measuring reducing sugars as a result of endoglucanase activity (Tomšovský et al. 2009; Dashtban et al. 2010; Longoni et al. 2012). CrC is a substrate similar to natural cellulose in the cell wall (Highley 1980; Tanaka et al. 2009; Kogo et al. 2017). During the degradation process, mycelial growth, $\mathrm{pH}$, cellulose degrading products (reducing sugars and glucose), cellulose related enzyme activities (CMCase and $\beta$-glucosidase) and total extracellular proteins will be measured.

\section{Materials and methods}

Fungal isolates: Samples of rotten woods and fungal fruiting bodies were collected from five different locations (Tervola, Rovaniemi, Joensuu, Viitasaari and Turku) in boreal forests in Finland. Samples were plated onto $2 \%$ malt extract agar (MEA) and incubated at $25^{\circ} \mathrm{C}$ until fungal growth was observed. Pure cultures were obtained by transferring the mycelium from the edges of single colonies. The pure fungal cultures were stored at $4^{\circ} \mathrm{C}$.

Fungal isolates were identified by molecular methods. The isolates were cultured on 2\% MEA prior to DNA extraction. Fungal DNA was extracted with the PrepMan Ultra Sample Preparation Reagent (Applied Biosystems, Foster City, CA, USA) following the kit user's manual. The DNA was amplified via polymerase chain reaction (PCR) with the internal transcribed spacer region (ITS1 and ITS2, including the 5.8 S gene) primers ITS1-F (Gardes and Bruns 1993) and ITS4 (White et al. 1990). The DNA was amplified in a $25 \mu \mathrm{l}$ reaction mixture that contained $0.25 \mu \mathrm{l}$ of Phusion ${ }^{\circledR}$ High-Fidelity DNA polymerase

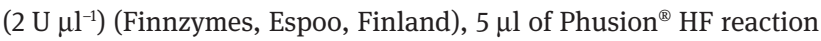
buffer $(5 \times), 0.75 \mu \mathrm{l}$ of $100 \%$ DMSO (supplied with the enzyme), $0.5 \mu \mathrm{l}$ of dNTP's (10 mM) (Finnzymes, Espoo, Finland) and $0.50 \mu \mathrm{l}$ of each primer (10 mM) (Invitrogen, Carlsbad, CA, USA). PCR reactions were performed on an ABI 2720 Thermal Cycler (Applied Biosystems, Foster City, CA, USA). The PCR conditions: an initial denaturation step at $98^{\circ} \mathrm{C}$ for $30 \mathrm{~s}$, followed by $35 \mathrm{cycles}$ per $10 \mathrm{~s}$ at $98^{\circ} \mathrm{C}, 30 \mathrm{~s}$ at $57^{\circ} \mathrm{C}$ and $30 \mathrm{~s}$ at $72^{\circ} \mathrm{C}$, and a final chain elongation at $72^{\circ} \mathrm{C}$ for $8 \mathrm{~min}$. Amplified products were visualized by the Lonza FlashGel System (Lonza Rockland Inc., Rockland, ME, USA).

PCR products were purified and sequenced at Macrogen Europe (Amsterdam, The Netherlands). Sequences were edited, and consensus sequences were determined by Geneious R8 8.0.3. All sequences obtained in this study were deposited in the GenBank (Table 1, Clark et al. 2015). The fungal isolates were identified by Megablast, searching the nucleotide database in GenBank (https://blast.ncbi.nlm.nih. gov/Blast.cgi). Identification was conducted with caution due to existence of misidentified sequences in the GenBank.
Screening of fungal isolates: All fungal isolates were tested for their ability to metabolize CMC as a carbon source by cultivating them on agar plates with and without $\mathrm{CMC}$ with three biological replicates. The agar plates were prepared with CMC $(0.1 \%$ CMC, Alfa Aesar, Ward Hill, MA, USA) ( $1 \mathrm{~g}$ of CMC, $1 \mathrm{~g}$ of $\mathrm{K}_{2} \mathrm{HPO}_{4}, 0.5 \mathrm{~g}$ of $\mathrm{MgSO}_{4} \cdot 7 \mathrm{H}_{2} \mathrm{O}, 0.5 \mathrm{~g}$ of $\mathrm{KCl}$, $0.01 \mathrm{~g}$ of $\mathrm{FeSO}_{4} \cdot 7 \mathrm{H}_{2} \mathrm{O}$ and $15 \mathrm{~g}$ of agar in $1 \mathrm{l}$ of pure water at $\mathrm{pH} 6.0$ ) and without $\mathrm{CMC}$. Isolates were cultivated at $22^{\circ} \mathrm{C}$, which is the median optimum for fungal growth, in the dark for 15 days. The radial growth was followed for 3 days. After the 15-days' cultivation, the agar plates were melted in hot water and filtered through Whatman qualitative filter paper Grade 1 (GE Healthcare, Chicago, IL, USA). The mycelium was separated from the filter paper with a pair of tweezers, dried on a weighing paper at $40^{\circ} \mathrm{C}$ overnight and weighed. To determine the optimal cultivation period, a preliminary 18-days' cultivation had been performed for four fungal isolates, one from each phyla or subphyla: Trichoderma polysporum (Ascomycota), A. sinuosa (Basidiomycota), Mortierella zychae (Mortierellomycotina) and Mucor sp. (Mucoromycotina).

The significance of the difference between fungi grown (dry weight) with and without CMC was analyzed by Student's t-test (P-value < 0.05) performed with R Version 3.3.1 (R: A Language and Environment for Statistical Computing, R Foundation for Statistical Computing, Vienna, Austria). The species (A. sinuosa) that had the greatest difference between the agars with and without CMC was chosen for further experiments.

In vitro cultivation of $\boldsymbol{A}$. sinuosa: The fungus was cultivated in $100 \mathrm{ml}$ Erlenmeyer flasks with $25 \mathrm{ml}$ of a liquid modified basal Douglas fir cotyledon revised medium [modified DCR: $400 \mathrm{mg}$ of $\mathrm{NH}_{4} \mathrm{NO}_{3}, 340 \mathrm{mg}$ of $\mathrm{KNO}_{3}, 85 \mathrm{mg}$ of $\mathrm{CaCl}_{2} \cdot 2 \mathrm{H}_{2} \mathrm{O}, 556 \mathrm{mg}$ of $\mathrm{Ca}\left(\mathrm{NO}_{3}\right)_{2} \cdot 4 \mathrm{H}_{2} \mathrm{O}, 170 \mathrm{mg}$ of $\mathrm{KH}_{2} \mathrm{PO}_{4}, 370 \mathrm{mg}$ of $\mathrm{MgSO}_{4} \cdot 7 \mathrm{H}_{2} \mathrm{O}, 39 \mathrm{mg}$ of Na-Fe-EDTA, $22.3 \mathrm{mg}$ of $\mathrm{MnSO}_{4} \cdot \mathrm{H}_{2} \mathrm{O}, 0.25 \mathrm{mg}$ of $\mathrm{CuSO}_{4} \cdot 5 \mathrm{H}_{2} \mathrm{O}, 8.6 \mathrm{mg}$ of $\mathrm{ZnSO}_{4} \cdot 7 \mathrm{H}_{2} \mathrm{O}, 6.2 \mathrm{mg}$ of $\mathrm{H}_{3} \mathrm{BO}_{3}, 0.25 \mathrm{mg}$ of $\mathrm{Na}_{2} \mathrm{MoO}_{4} \cdot 2 \mathrm{H}_{2} \mathrm{O}, 0.025 \mathrm{mg}$ of $\mathrm{CoCl}_{2} \cdot 6 \mathrm{H}_{2} \mathrm{O}, 0.83 \mathrm{mg}$ of $\mathrm{KI}, 0.025 \mathrm{mg}$ of $\mathrm{NiCl}_{2}, 1 \mathrm{mg}$ of thiamine- $\mathrm{HCl}, 0.5 \mathrm{mg}$ of pyridoxin- $\mathrm{HCl}$, $0.5 \mathrm{mg}$ of nicotinic acid and $2 \mathrm{mg}$ of glycine in 11 of pure water at $\mathrm{pH}$ 6.0] (Gupta and Durzan 1985) containing $1 \mathrm{~g}$ of CMC as a sole carbon source. The $\mathrm{pH}$ value was adjusted to 5.7. The liquid cultivations were inoculated from freshly cultured MEA plates with a $7 \mathrm{~mm}$ diameter agar plug. A total of 18 flasks of $A$. sinuosa in the medium was prepared; three biological replicates for each six destructive sampling. Fungi were incubated under constant normal conditions at $25^{\circ} \mathrm{C}$ with shaking (100 rpm) (MaxQ 4000, Thermo Fisher Scientific, Waltham, MA, USA) for 15 days and sampled every 3 days.

After 15 days cultivation, the culture $\mathrm{pH}$ was measured, and visible fungal mycelium was weighed after filtering as described. The remaining culture medium was sterile filtered through a $0.2 \mu \mathrm{m}$ syringe filter (VWR international, Radnor, PA, USA) to remove spores and all mycelium and stored at $-20^{\circ} \mathrm{C}$ for further analyses.

The increase of mycelial dry weight reflects the amount of CMC consumption, which was determined via measuring reducing sugars by means of the dinitrosalicylic acid (DNS) method (Wood and Bhat 1988; Fu et al. 2010). The concentration of glucose was measured via the Glucose (GO) Assay Kit (Sigma-Aldrich, St Louis, MO, USA) according to manufacturer's instructions. The absorbance at $540 \mathrm{~nm}$ was measured with a spectrophotometer (UV-1800 UV Spectrophotometer, Shimadzu Corporation, Kyoto, Japan) with glucose as standard.

To assess the enzyme production of the fungal isolate, the concentration of total extracellular proteins was determined by the Coomassie (Bradford) Protein Assay kit (Thermo Fisher Scientific, Waltham, MA, USA) according to manufacturer's instructions, with bovine serum albumin (BSA) as standard. The extracellular enzyme 
Table 1: Fungal species isolated from rotten wood and fruit bodies in Finland.

\begin{tabular}{|c|c|c|c|c|c|}
\hline $\begin{array}{l}\text { Phylum/Subphylum } \\
\text { Species name }\end{array}$ & Pers.ID no. & CBS $^{\mathrm{a}}$ no. & Host & Origin & GenBank acc. no. \\
\hline \multicolumn{6}{|l|}{ Ascomycota } \\
\hline Trichoderma polysporum & 1 & 142256 & Picea abies (L.) H. Karst. & Tervola & KP174729 \\
\hline T. polysporum & 27 & & Coniferous wood ${ }^{b}$ & Tervola & KP174753 \\
\hline T. polysporum & 14 & & Mycorrhizal & Tervola & KP174741 \\
\hline Trichoderma pulvinatum & 40 & & Polypore & Tervola & KP174763 \\
\hline T. pulvinatum & 13 & 142265 & Fomitopsis pinicola & Joensuu & KP174740 \\
\hline Trichoderma paraviridescens & 36 & 142275 & Coniferous wood ${ }^{\mathrm{b}}$ & Joensuu & KP174761 \\
\hline Trichoderma viride & 18 & 142269 & Phellinus sp. & Tervola & KP174745 \\
\hline T. viride & 19 & & Pholiota sp. & Tervola & KP174746 \\
\hline T. viride & 20 & & Coniferous wood ${ }^{\mathrm{b}}$ & Tervola & KP174747 \\
\hline T. viride & 22 & & Phellinus sp. & Tervola & KP174749 \\
\hline Trichoderma hamatum & 26 & 142271 & Prunus padus L. & Turku & KP174752 \\
\hline Trichoderma atroviride & 4 & 142259 & Unknown & Tervola & KP174732 \\
\hline Monographella lycopodina & 11 & 142263 & Phellinus sp. & Tervola & KP174738 \\
\hline Scytalidium lignicola & 32 & 142274 & Stump of Betula sp. L. & Viitasaari & KP174757 \\
\hline Phoma sp. & 37 & & Pinus sylvestris L. (d.w.c) & Rovaniemi & KP174762 \\
\hline Phoma sp. & 15 & 142266 & Mycorrhizal & Tervola & KP174742 \\
\hline \multicolumn{6}{|l|}{ Basidiomycota } \\
\hline Antrodia sinuosa & 43 & 142277 & Coniferous wood ${ }^{\mathrm{b}}$ & Tervola & KP174765 \\
\hline Antrodia xantha & 24 & 142270 & Coniferous wood ${ }^{b}$ & Tervola & KP174751 \\
\hline Fomitopsis pinicola & 42 & 142276 & Coniferous wood ${ }^{b}$ & Tervola & KP174764 \\
\hline Gloeophyllum sepiarium & 31 & 142272 & Picea abies (L.) H. Karst. & Tervola & KP174756 \\
\hline G. sepiarium & 34 & & Coniferous wood ${ }^{b}$ & Tervola & KР174759 \\
\hline Irpex lacteus & 2 & 142257 & Prunus padus L. & Turku & KP174730 \\
\hline Pleurotus sp. & 29 & 142273 & Unknown & Joensuu & KP174755 \\
\hline Trametes pubescens & 44 & 142278 & Deciduous wood & Joensuu & KP174766 \\
\hline Bjerkandera adusta & 45 & 142279 & Unknown & Joensuu & KP174767 \\
\hline \multicolumn{6}{|l|}{ Mortierellomycotina } \\
\hline Mortierella hyalina & 9 & 142262 & Salix caprea L. & Tervola & KP174737 \\
\hline M. hyalina & 21 & & Deciduous wood & Tervola & KP174748 \\
\hline M. hyalina & 23 & & Deciduous wood & Tervola & KP174750 \\
\hline M. hyalina & 35 & & Coniferous wood ${ }^{b}$ & Tervola & KP174760 \\
\hline Mortierella alpina & 3 & 142258 & Unknown & Tervola & KP174731 \\
\hline Mortierella zychae & 6 & & Phellinus sp. & Joensuu & KP174734 \\
\hline Mortierella verticillata & 5 & 142260 & Coniferous wood ${ }^{\mathrm{b}}$ & Tervola & KP174733 \\
\hline \multicolumn{6}{|l|}{ Mucoromycotina } \\
\hline Mucor sp. & 7 & 142261 & Crustoderma dryinum & Tervola & KP174735 \\
\hline Umbelopsis ramanniana & 16 & 142267 & Picea abies (L.) H. Karst. & Tervola & KP174743 \\
\hline Umbelopsis isabellina & 12 & 142264 & Prunus padus L. & Tervola & KP174739 \\
\hline U. isabellina & 28 & & Unknown & Viitasaari & KP174754 \\
\hline Absidia psychrophilia & 17 & 142268 & Picea abies (L.) H. Karst. & Tervola & KP174744 \\
\hline
\end{tabular}

${ }^{a}$ CBS: Westerdijk Fungal Biodiversity Institute, Utrecht, the Netherlands; ${ }^{\mathrm{b}}$ Picea abies or Pinus sylvestris; 'dry wood.

activity measurements were based on the release rate of reducing sugars [indicating CMCase and filter paper cellulase (FPase) as endoglucanases for amorphous and $\mathrm{CrC}$ degradation] and glucose (indicating $\beta$-glucosidase). The methods of literature have been applied with slight modifications as indicated in the following: For the CMCase activity measurement (Ghose 1987; Fu et al. 2010), $0.5 \mathrm{ml}$ of each sample medium was mixed with $0.5 \mathrm{ml}$ of $2 \%(\mathrm{w} / \mathrm{v}) \mathrm{CMC}$ solution in $0.05 \mathrm{M}$ citrate buffer ( $\mathrm{pH} \mathrm{4.8)}$ ) and incubated at $50^{\circ} \mathrm{C}$ for $30 \mathrm{~min}$. Then, $0.5 \mathrm{ml}$ of the incubated solution was reacted with $1.5 \mathrm{ml}$ of DNS reagent at $100^{\circ} \mathrm{C}$ for $5 \mathrm{~min}$. After cooling down, water $(8 \mathrm{ml})$ was added.
For FPase activity (Wood and Bhat 1988), a rolled strip of Whatman No. 1 filter paper $(1 \times 6 \mathrm{~cm}), 1 \mathrm{ml}$ of $0.05 \mathrm{M}$ citrate buffer $(\mathrm{pH} \mathrm{4.8)}$ and $0.5 \mathrm{ml}$ of sample medium were introduced into $50 \mathrm{ml}$ capacity test tube. After incubating the test tube at $50^{\circ} \mathrm{C}$ for $60 \mathrm{~min}, 3 \mathrm{ml}$ of DNS was added and boiled for $5 \mathrm{~min}$. After cooling, $20 \mathrm{ml}$ of distilled water was added and kept in the test tubes for $20 \mathrm{~min}$. For $\beta$-glucosidase activity (Sternberg 1976; Lowe et al. 1987; Yoon et al. 2008), $0.5 \mathrm{ml}$ of each sample medium and $0.5 \mathrm{ml}$ of $10 \mathrm{mM}$ cellobiose solution in $100 \mathrm{mM}$ sodium acetate buffer ( $\mathrm{pH}$ 5.0) were mixed and incubated at $50^{\circ} \mathrm{C}$ for $30 \mathrm{~min}$. Then the incubated samples were boiled for $5 \mathrm{~min}$. 
The spectrophotometric analyses were performed as described. The enzymatic activities were calculated as $1 \mu \mathrm{mol}$ of Glc $\mathrm{min}^{-1} \mathrm{ml}^{-1}$ of medium and expressed as 1 unit $\mathrm{ml}^{-1}$. The same experiments were conducted with $\mathrm{CrC}$ instead of $\mathrm{CMC}$ in the culture medium.

\section{Results and discussion}

\section{Screening of the species}

In total, 37 fungal strains (from 25 species) were isolated from rotten wood or fruiting bodies in a boreal forest in Finland (Table 1). Many of them were wood-decay polypores (Polyporales, Basidiomycota) that were already described as lignocellulose degrading fungi (Mansfield et al. 1998; Elisashvili et al. 2008; Tomšovský et al. 2009; Casieri et al. 2010; Quiroz-Castañeda et al. 2011). The species represent the members of the fungal phyla and subphyla Ascomycota, Basidiomycota, Mortierellomycotina and Mucoromycotina.

In the preliminary growth test concerning the cultivation period of fungi, mycelial dry weights of T. polysporum and $A$. sinuosa were higher in the case when grown on agar with CMC (Figure S1a,b). The difference became larger with longer cultivation time. The mycelial dry weights of $M$. zychae and Mucor sp. were about the same with or without CMC (Figure S1c, d). The fungal growth, except for T. polysporum, reached a steady state within 15 days. Therefore, the species were cultured for 15 days in the screening test, in which all species were able to grow on the plate in the absence of CMC and some species even preferred agar as a carbon source (Figure 1). However, several fungal species had higher mycelial dry weight after growing on agar plates with CMC than without CMC. Five out of the 37 isolates, namely two isolates of T. polysporum (personal isolate No. 1 and 14), A. sinuosa (No. 43, CBS 142277), Mucor sp. (No. 7) and Absidia psychrophilia (No. 17), showed significantly higher mycelial dry weight on the plates with CMC than without ( $\mathrm{t}$-test, $\mathrm{P}<0.05)$. Obviously, these five species preferred CMC instead of agar as a carbon source.

Antrodia sinuosa was selected for further investigation because the difference of the dry weight between the plates with and without CMC was twice as great among the isolated species. Cultivation on agar plates confirmed the ability of $A$. sinuosa for cellulose degradation. The mycelial dry weight on CMC plates was $2.4 \mathrm{mg}$ and without CMC $1.2 \mathrm{mg}$ (Figure 1). Moreover, the growth rate of the mycelia on CMC plates was $2.3 \mathrm{~mm} \mathrm{day}^{-1}$ and without CMC $2.1 \mathrm{~mm}$ day $^{-1}$. Accordingly, A. sinuosa needed CMC to build cell biomass although it was able to also grow without CMC. Antrodia sinuosa was studied before for its wood decay efficiency and agricultural influence (Bigelow et al. 1998; Matheron et al. 2006; Brischke et al. 2008) but neither its cellulose degradation in vitro, nor its biochemical changes in the initial stage of cellulose degradation were hitherto observed.

\section{Cellulolytic activity of $A$. sinuosa in vitro cultivation}

The mycelial dry weight of $A$. sinuosa showed an increasing trend until the $12^{\text {th }}$ day during the 15-days'

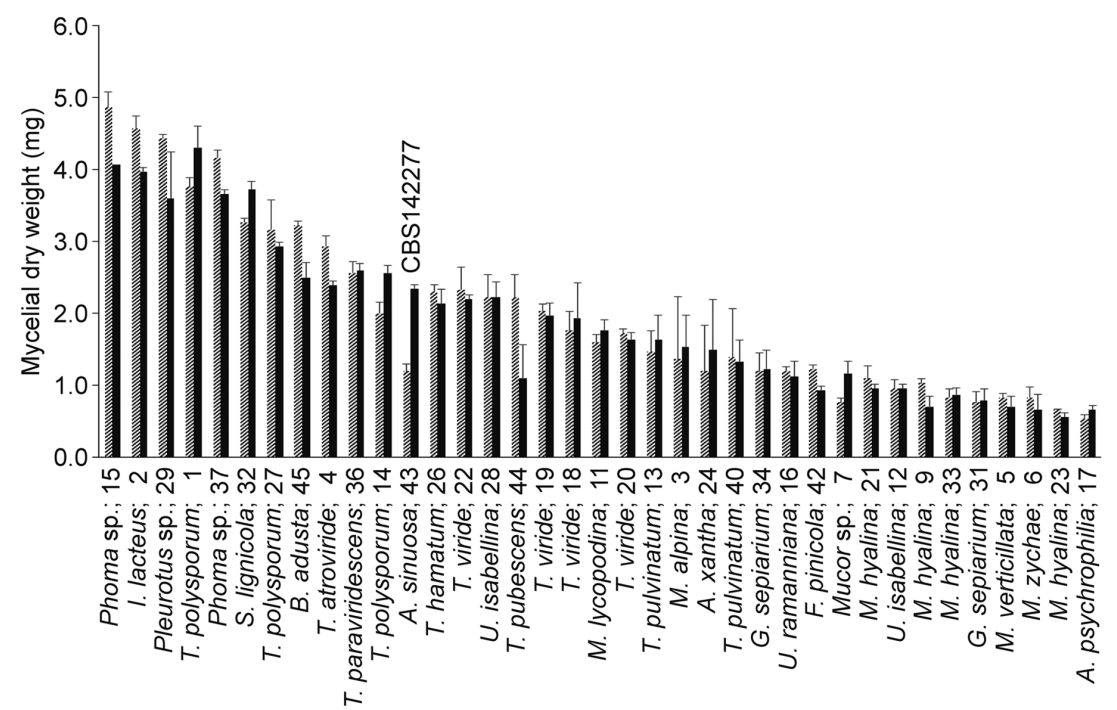

Figure 1: Mycelial dry weight of fungal isolates grown on agar without (shaded bars) and with (black bars) CMC for 15 days. The numbers after species refer to the personal isolation number. Error bars refer to standard deviation (SD) $(n=3)$. 
cultivation in liquid medium with $\mathrm{CMC}$ as a sole carbon source (Figure 2a). The maximum growth rate was $0.6 \mathrm{mg} \mathrm{day}{ }^{-1}$ from the $3^{\text {rd }}$ to the $6^{\text {th }}$ day, which was slowed down after 6 day. The maximum dry weight (3.9 mg) was observed on the $12^{\text {th }}$ growing day. The $\mathrm{pH}$ value of the culture medium decreased after the inoculation day ( $\mathrm{pH}$ 5.7) (Figure 2a). A considerable drop in the $\mathrm{pH}$ was observed from the $3^{\text {rd }}$ to the $6^{\text {th }}$ day, from $\mathrm{pH} 5.4$
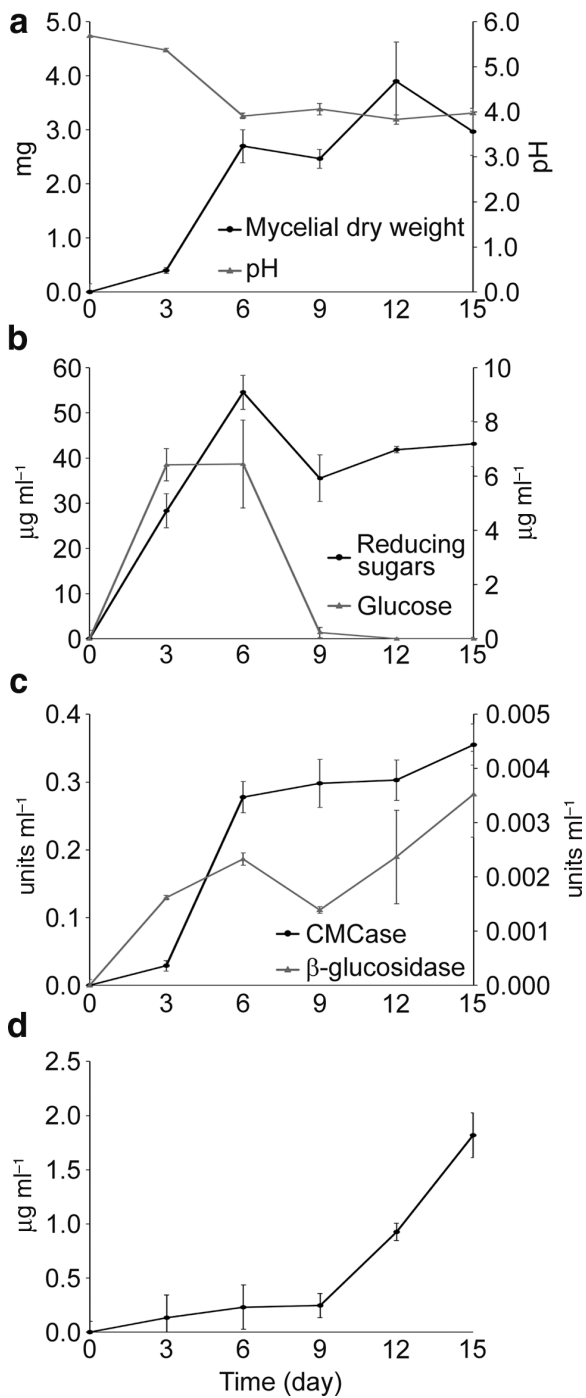

Figure 2: Correlations of cell growth of $A$. sinuosa and CMC degradation activities.

(a) Mycelial dry weight (left y-axis) of $A$. sinuosa grown in liquid culture medium with $\mathrm{CMC}$ and the $\mathrm{pH}$ (right $\mathrm{y}$-axis) of the culture medium during the incubation. (b) Concentrations of reducing sugars and glucose (the left and right y-axes, respectively) in A. sinuosa culture medium with CMC during the incubation. (c) Extracellular CMCase and $\beta$-glucosidase (the left and right $y$-axes, respectively) activity during the incubation. (d) Total extracellular protein concentrations in $A$. sinuosa culture medium with CMC during the incubation. Error bars refer to SD $(n=3)$. to $\mathrm{pH} 3.9$ and the $\mathrm{pH}$ was equilibrated to a nearly constant $\mathrm{pH} 4$.

In the incubation with CMC, the increase of $A$. sinuos $a$ mycelial weight coincided with the decrease of culture medium $\mathrm{pH}$, from $\mathrm{pH} 5.7$ to 3.9. Thus, $\approx \mathrm{pH} 4$ was the optimum for the $A$. sinuosa growth. The same optimum was previously observed for A. camphorata (Shu and Lung 2004) and the optimal $\mathrm{pH}$ of cellulolytic hydrolase in general seems to be between 2.5 and 4.5 (Baldrian 2008). Several acidic compounds were identified in the culture medium of another Antrodia species, e.g. A. cinnamomea (Wu et al. 2011). Our results can be interpreted that $A$. sinuosa produces acid metabolites at the early stage of cellulose degradation, which are leading to an optimized $\mathrm{pH}$. The oxalic acid production of brown-rot fungi is known in the context of Fenton reaction (Arantes and Goodell 2014). Nevertheless, the causality of the $\mathrm{pH}$ and cellulase activities in the case of Antrodia species needs to be studied in more detail.

The concentration of reducing sugars increased after inoculation but decreased from the $6^{\text {th }}$ to the $9^{\text {th }}$ day and slightly increased again until the $15^{\text {th }}$ day (Figure $2 \mathrm{~b}$ ). The maximum concentration of the reducing sugars was 54.6 $\mu \mathrm{g} \mathrm{ml}^{-1}$ on the $6^{\text {th }}$ day. The glucose concentration increased from the inoculation day to the $3^{\text {rd }}$ day and was relatively high until the $6^{\text {th }}$ day (Figure 2b), with a maximum of $6.5 \mu \mathrm{g} \mathrm{ml}^{-1}$ and then decreased to a relatively low level. The CMCase activity increased slightly until the $3^{\text {rd }}$ day (Figure 2c) and increased rapidly between the $3^{\text {rd }}$ and $6^{\text {th }}$ day and later the increment was moderate and ended up with a maximum of $0.36 \mathrm{U} \mathrm{ml}^{-1}$. The $\beta$-glucosidase activity increased relatively sharply until the $6^{\text {th }}$ day (Figure 2c) and decreased between the $6^{\text {th }}$ and $9^{\text {th }}$ day and increased again beyond this time to reach a maximum at the $15^{\text {th }}$ day $\left(0.0035 \mathrm{U} \mathrm{ml}^{-1}\right)$. The FPase activity, which indicates $\mathrm{CrC}$ degradation, hardly changed during the cultivation in the CMC medium, only a slight increment was observed (Figure S2). It can be assumed that the fungus does not have enzymatic activity against $\mathrm{CrC}$ as the cultivating substrate was CMC. Therefore, FPase activity measurement was not especially useful in this context.

The fungus produced CMCase that degraded the polymeric structure of CMC into oligomers, i.e. reducing sugars. The increase of glucose concentration indicate that these oligomers were further degraded into monomers, i.e. glucose, by $\beta$-glucosidase, as described by Lynd et al. (2002) and Rytioja et al. (2014). Concerning the initial stage of CMC degradation by $A$. sinuosa, the cellulose conversion into oligomers is more efficient than that of oligomers into glucose. This result is meaningful considering of industrial applications, where the requirement 
to use lignocellulosic biomass is that after the fungal saccharification, sugars should be converted into ethanol by yeasts. It was reported that an engineered Saccharomyces cerevisiae can consume cellobiose effectively and ferment it to ethanol (Ha et al. 2011). Therefore, A. sinuosa could be a promising fungus as cellobiose provider for ethanol production.

The concentration of total extracellular proteins remained on a relatively low level until the $9^{\text {th }}$ day (Figure 2d) and then increased rapidly until the maximum $\left(1.8 \mu \mathrm{g} \mathrm{ml}^{-1}\right)$ was reached on the $15^{\text {th }}$ day. Antrodia species produce endoglucanase and $\beta$-glucosidase (Tomšovský et al. 2009) and the gene models for these enzymes were detected in the $A$. sinuosa genome [Joint Genome Institute (JGI) website (https://jgi.doe.gov/)]. Therefore, the CMCase and $\beta$-glucosidase activities detected in the present paper are in line with the literature data.

No significant changes were observed in the presence of $\mathrm{CrC}$ in the culture medium but all values were lower than the respective values with CMC in the culture medium. The mycelial dry weights could not be measured accurately because the aggregates with the $\mathrm{CrC}$ powder and the mycelia could not be separated. The $\mathrm{pH}$ value slightly decreased after the inoculation day and was the lowest ( $\mathrm{pH}$ 5.05) on the $12^{\text {th }}$ day (Figure S3). The concentration of reducing sugars increased after inoculation and decreased from the $3^{\text {rd }}$ to the $6^{\text {th }}$ day and slightly increased again from the $12^{\text {th }}$ day on (Figure S4a). The glucose concentration increased from the inoculation day to the $3^{\text {rd }}$ day and then decreased to a low level (Figure S4a). The CMCase activity increased gradually from the inoculation day and reached a maximum on the15 ${ }^{\text {th }}$ day $\left(0.081 \mathrm{U} \mathrm{ml}^{-1}\right)$ (Figure $\left.\mathrm{S} 4 \mathrm{~b}\right)$. The $\beta$-glucosidase activity increased from the inoculation day to the $3^{\text {rd }}$ day to its maximum $\left(0.0008 \mathrm{U} \mathrm{ml}^{-1}\right)$ and then decreased (Figure S4b). The total extracellular protein concentration increased until the $3^{\text {rd }}$ day and then decreased until the $12^{\text {th }}$ day and increased rapidly after the $12^{\text {th }}$ day again (Figure S5). The end point of total protein concentration reached similar amount as seen in the CMC culture medium. Filter paper is composed of $\mathrm{CrC}$ and thus, it can be assumed that the FPase activity should have been higher for $\mathrm{CrC}$ than CMC. However, the FPase activity was almost steady and slightly lower for the $\mathrm{CrC}$ culture medium compared to that with CMC (Figure S2). In contrast to previous reports which showed efficient CrC degradation by cellulases of some brown-rot species (Cohen et al. 2005; Lee et al. 2008), CrC did not induce production of cellulases in A. sinuosa. Therefore, the conclusions can be drawn based on CMC degradation alone.

\section{Conclusions}

Antrodia sinuosa, a brown-rot fungus, was found to be a promising species for industrial cellulose degradation. Antrodia sinuosa metabolized CMC to support its growth and produced cellulolytic enzymes in the initial cultivation period. Cellulase activities were seen at the initial stage of CMC degradation, but the optimization of reducing sugars was not achieved. This illustrated the challenge for industrial scale application of fungi. The species specific interactions must be better understood, and the culture condition and the degradation process must be further optimized. Antrodia sinuosa needs an optimal $\mathrm{pH}$ for its effective growth. By self-regulating its $\mathrm{pH}$ environment, the fungus can survive and grow under poor conditions even when it lacks the perfect nutrient. It can colonize and metabolize the biomass faster than other species. After the first steps of the present research, more investigation is needed to evaluate the full potential of $A$. sinuosa in biotechnological applications. Co-cultivation studies of several species and finding a suitable species combination could be helpful in this context.

Acknowledgments: We thank the staff at the Botanical Garden, the University of Turku and the University of Eastern Finland for their supports in conducting this study. We appreciate Joanna Kowalczyk, Kristiina Hildén, Elizabeth Nyman and Oili Kiikkilä for commenting on and proofreading this paper.

Author contributions: All the authors have accepted responsibility for the entire content of this submitted manuscript and approved submission.

Research funding: JS was financially supported by the University of Turku and the KONE Foundation, Funder Id: 10.13039/501100005781 (grant numbers 33-2378, 44-8103, 55-15747, 71-28532), Finland. RL was financially supported by the University of Helsinki.

Employment or leadership: None declared.

Honorarium: None declared.

\section{References}

Agematu, H., Takahashi, T., Hamano, Y. (2017) Continuous volatile fatty acid production from lignocellulosic biomass by a novel rumen-mimetic bioprocess. J. Biosci. Bioeng. 124:528-533.

Arantes, V., Goodell, B. (2014) Current understanding of brown-rot fungal biodegradation mechanisms: A review. In: Deterioration and protection of sustainable biomaterials. Eds. Schultz, T.P., Goodell, B., Nicholas, D.D. Oxford University Press, Oxford. pp. 3-21. 
Bak, J.S., Ko, J.K., Choi, I-G., Park, Y-C., Seo, J-H., Kim, K.H. (2009) Fungal pretreatment of lignocellulose by Phanerochaete chrysosporium to produce ethanol from rice straw. Biotechnol. Bioeng. 104:471-482.

Balan, V. (2014) Current challenges in commercially producing biofuels from lignocellulosic biomass. ISRN Biotechnol. 2014: Article ID 463074, 31 pages.

Baldrian, P. (2008) Chapter 2 Enzymes of saprotrophic basidiomycetes. Br. Mycol. Soc. Symp. 28:19-41.

Bigelow, D.M., Gilbertson, R.L., Matheron, M.E. (1998) Cultural studies of fungi causing brown rot in heartwood of living lemon trees in Arizona. Mycol. Res. 102:257-262.

Brischke, C., Welzbacher, C.R., Huckfeldt, T. (2008) Influence of fungal decay by different basidiomycetes on the structural integrity of Norway spruce wood. Holz Roh Werkst. 66:433-438.

Casieri, L., Anastasi, A., Prigione, V., Varese, G.C. (2010) Survey of ectomycorrhizal, litter-degrading, and wood-degrading Basidiomycetes for dye decolorization and ligninolytic enzyme activity. Antonie van Leeuwenhoek 98:483-504.

Clark, K., Karsch-Mizrachi, I., Lipman, D.J., Ostell, J., Sayers, E.W. (2015) GenBank. Nucleic Acids Res. 44:D67-72.

Cohen, R., Suzuki, M.R., Hammel, K.E. (2005) Processive endoglucanase active in crystalline cellulose hydrolysis by the brown rot basidiomycete Gloeophyllum trabeum. Appl. Environ. Microbiol. 71:2412-2417.

Dashtban, M., Maki, M., Leung, K.T., Mao, C., Qin, W. (2010) Cellulase activities in biomass conversion: measurement methods and comparison. Crit. Rev. Biotechnol. 30:302-309.

Deepa, B., Abraham, E., Cordeiro, N., Mozetic, M., Mathew, A.P., Oksman, K., Faria, M., Thomas, S., Pothan, L.A. (2015) Utilization of various lignocellulosic biomass for the production of nanocellulose: a comparative study. Cellulose 22:1075-1090.

Dias, A.A., Freitas, G.S., Marques, G.S.M., Sampaio, A., Fraga, I.S., Rodrigues, M.A.M., Evtuguin, D.V., Bezerra, R.M.F. (2010) Enzymatic saccharification of biologically pre-treated wheat straw with white-rot fungi. Bioresour. Technol. 101:6045-6050.

Elisashvili, V., Kachlishvili, E., Penninckx, M. (2008) Effect of growth substrate, method of fermentation, and nitrogen source on lignocellulose-degrading enzymes production by white-rot basidiomycetes. J. Ind. Microbiol. Biotechnol. 35:1531-1538.

Fu, C.C., Hung, T.C., Chen, J.Y., Su, C.H., Wu, W.T. (2010) Hydrolysis of microalgae cell walls for production of reducing sugar and lipid extraction. Bioresour. Technol. 101:8750-8754.

Gardes, M., Bruns, T.D. (1993) ITS primers with enhanced specificity for basidiomycetes - application to the identification of mycorrhizae and rusts. Mol. Ecol. 2:113-118.

Ghose, T.K. (1987) Measurement of cellulase activities. Pure Appl. Chem. 59:257-268.

Guerriero, G., Hausman, J-F., Strauss, J., Ertan, H., Siddiqui, K.S. (2016) Lignocellulosic biomass: biosynthesis, degradation, and industrial utilization. Eng. Life Sci. 16:1-16.

Gupta, P.K., Durzan, D.J. (1985) Shoot multiplication from mature trees of Douglas-fir (Pseudotsuga menziesii) and sugar pine (Pinus lambertiana). Plant Cell Rep. 4:177-179.

Ha, S-J., Galazka, J.M., Kim, S.R., Choi, J-H., Yang, X., Seo, J-H., Glass, N.L., Cate, J.H.D., Jin, Y-S. (2011) Engineered Saccharomyces cerevisiae capable of simultaneous cellobiose and xylose fermentation. PNAS 108:504-509.

Highley, T.L. (1980) Cellulose degradation by cellulose-clearing and non-cellulose clearing brown-rot fungi. Appl. Environ. Microbiol. 40:1145-1147.
Himmel, M.E., Ding, S-Y., Johnson, D.K., Adney, W.S., Nimlos, M.R., Brady, J.W., Foust, T.D. (2007) Biomass recalcitrance: Engineering plants and enzymes for biofuels production. Science 315:804-807.

Keller, F.A., Hamilton, J.E., Nguyen, Q.A. (2003) Microbial pretreatment of biomass: Potential for reducing severity of thermochemical biomass pretrearment. Appl. Biochem. Biotech. 105:27-41.

Kogo, T., Yoshida, Y., Koganei, K., Matsumoto, H., Watanabe, T., Ogihara, J., Kasumi, T. (2017) Production of rice straw hydrolysis enzymes by the fungi Trichoderma reesei and Humicola insolens using rice straw as a carbon source. Bioresour. Technol. 233:67-73.

Kumar, R., Singh, S., Singh, O.V. (2008) Bioconversion of lignocellulosic biomass: biochemical and molecular perspectives. J. Ind. Microbiol. Biotechnol. 35:377-391.

Kumar, M., Campbell, L., Turner, S. (2016) Secondary cell walls: biosynthesis and manipulation. J. Exp. Bot. 67:515-531.

Lee, L-W., Kim, H-Y., Koo, B-W., Choi, D-H., Kwon, M., Choi, I-G. (2008) Enzymatic saccharification of biologically pretreated Pinus densiflora using enzymes from brown rot fungi. J. Biosci. Bioeng. 106:162-167.

Longoni, P., Rodolfi, M., Pantaleoni, L., Doria, E., Concia, L., Picco, A.M., Cella, R. (2012) Functional analysis of the degradation of cellulosic substrates by a Chaetomium globosum endophytic isolate. Appl. Environ. Microbiol. 78:3693-3705.

Lowe, S.E., Theodorou, M.K., Trinci, A.P.J. (1987) Cellulase and xylanase of an anaerobic rumen fungus grown on wheat straw holocellulose, cellulose, and xylan. Appl. Environ. Microb. 53:1216-1223.

Lynd, L.R., Weimer, P.J., van Zyl, W.H., Pretorius, I.S. (2002) Microbial cellulose utilization: fundamental and biotechnology. Microbiol. Mol. Biol. R. 66:506-577.

Mansfield, S.D., Saddler, J.N., Gübitz, G.M. (1998) Characterization of endoglucanases from the brown rot fungi Gloeophyllum sepiarium and Gloeophyllum trabeum. Enzyme Microb. Tech. 23:133-140.

Matheron, M.E., Porchas, M., Bigelow, D.M. (2006) Factors affecting the development of wood rot on lemon trees infected with Antrodia sinuosa, Coniophora eremophila, and a Nodulisporium sp. Plant Dis. 90:554-558.

Mathews, S.L., Grunden, A.M., Pawlak, J. (2016) Degradation of lignocellulose and lignin by Paenibacillus glucanolyticus. Int. Biodeterior. Biodegradation. 110:79-86.

Mosier, N., Wyman, C., Dale, B., Elander, R., Lee, Y.Y., Holtzapple, M., Ladisch, M. (2005) Features of promising technologies for pretreatment of lignocellulosic biomass. Bioresource Technol. 96:673-686.

Quiroz-Castañeda, R.E., Martínez-Anaya, C., Cuervo-Soto, L.I., Segovia, L., Folch-Mallol, J.L. (2011) Loosenin, a novel protein with cellulose-disrupting activity from Bjerkandera adusta. Microb. Cell. Fact. 10:8.

Renvall, P. (1995) Community structure and dynamics of woodrotting Basidiomycetes on decomposing conifer trunks in northern Finland. Karstenia 35:1-51.

Rytioja, J., Hildén, K., Yuzon, J., Hatakka, A., de Vries, R.P., Mäkelä, M.R. (2014) Plant-polysaccharide-degradation enzymes from basidiomycetes. Microbiol. Mol. Biol. R. 78:614-649.

Schmidt, O., Moreth, U. (1996) Biological characterization of Poria indoor brown-rot fungi. Holzforschung 50:105-110. 
Shi, J., Sharma-Shivappa, R.R., Chinn, M., Howell, N. (2009) Effect of microbial pretreatment on enzymatic hydrolysis and fermentation of cotton stalks for ethanol production. Biomass Bioenergy 33:88-96.

Shirkavand, E., Baroutian, S., Gapes, D.J., Young, B.R. (2016) Combination of fungal and physicochemical processes for lignocellulosic biomass pretreatment - a review. Renew. Sustainable Energy Rev. 54:217-234.

Shu, C.H., Lung, M.Y. (2004) Effect of $\mathrm{pH}$ the production and molecular weight distribution of exopolysaccharide by Antrodia camphorata in batch cultures. Process Biochem. 39:931-937.

Sindhu, R., Binod, P., Pandey, A. (2016) Biological pretreatment of lignocellulosic biomass - an overview. Bioresour. Technol. 199:76-82.

Sternberg, D. (1976) $\beta$-glucosidase of Trichoderma: Its biosynthesis and role in saccharification of cellulose. Appl. Environ. Microbiol. 31:648-654.

Tanaka, H., Koike, K., Itakura, S., Enoki, A. (2009) Degradation of wood and enzyme production by Ceriporiopsis subvermispora. Enzyme Microb. Technol. 45:384-390.

Tomšovský, M., Popelářová, P., Baldrian, P. (2009) Production and regulation of lignocellulose-degrading enzymes of Poria-like wood-inhabiting basidiomycetes. Folia. Microbiol. 54:74-80.

van Kuijk, S.J.A., Sonnenberg, A.S.M., Baars, J.J.P., Hendriks, W.H., Cone, J.W. (2015) Fungal treatment of lignocellulosic biomass: importance of fungal species colonization and time on chemi- cal composition and in vitro rumen degradability. Anim. Feed Sci. Tech. 209:40-50.

Wan, C., Li, Y. (2012) Fungal pretreatment of lignocellulose biomass. Biotechnol. Adv. 30:1447-1457.

White, T.J., Bruns, T., Lee, S., Taylor, J.W. (1990) Amplification and direct sequencing of fungal ribosomal RNA genes for phylogenetics. In: PCR Protocols: A Guide to Method and Applications. Eds. Innis, M.A., Gelfand, D.H., Sninsky, J.J., White, TJ. Academic Press, Inc., New York. pp. 315-322.

Wood, T.M., Bhat, K.M. (1988) Methods for measuring cellulase activities. Methods Enzymol. 160:87-112.

Wu, M.D., Chen, M.J., Wang, W.Y., Huang, H.C., Yuan, G.F., Chen, J.J., Chen, I.S., Wang, B.C. (2011) Antioxidant activities of extracts and metabolites isolated from the fungus Antrodia cinnamomea. Nat. Prod. Res. 25:1488-1496.

Xu, C., Ma, F., Zhang, X. (2009) Lignocellulose degradation and enzyme production by Irpex lacteus CD2 during solid-state fermentation of corn stover. J. Biosci. Bioeng. 108:372-375.

Yoon, J.J., Kim, K.Y., Cha, C.J. (2008) Purification and characterization of thermostable $\beta$-glucosidase from the brown-rot basidiomycete Fomitopsis palustris grown on microcrystalline cellulose. J. Microbiol. 46:51-55.

Supplementary Material: The online version of this article offers supplementary material (https://doi.org/10.1515/hf-2018-0145). 